\title{
Commercial thinning effects on growth, yield and mortality in natural lodgepole pine stands in Alberta
}

\author{
by Sanatan Das Gupta ${ }^{1 *}$, Bradley D. Pinno ${ }^{1}$ and Tim McCready²
}

\begin{abstract}
There is an expected decrease in the short to mid-term timber supply of lodgepole pine (Pinus contorta var. latifolia) in Alberta, Canada due to the impacts of past fires and the mountain pine beetle outbreak. Commercial thinning is a potential option for increasing mid-term sawlog timber supply by decreasing the time needed for individual trees to reach merchantable size, through providing access to fiber earlier in the rotation, and from the ability to keep mature stands on the stump longer. In the current study, we evaluated the effects of commercial thinning in stands of different ages. Stands less than 70 years old at thinning were classified as commercial thinning (CT), whereas stands greater than 70 years at thinning were classified as salvage thinning (ST). Tree growth and survival were measured every five years from 1996 to 2016 in both thinned and unthinned stands. Fifteen years post-thinning, stand volume was less in the thinned stands relative to the unthinned controls. However, when volume removed at thinning was considered, volume gain from thinned stands was greater than that from the controls in both thinning treatments. Individual tree DBH and live crown ratio were also greater in thinned stands relative to controls. Thinning favored diameter gain mostly in the medium-sized trees in CT but both small to medium-sized trees in ST. Thinning reduced mortality in all stands relative to the controls and a maximum of 50\% reduction in mortality was observed in CT. Overall, the findings suggest that natural lodgepole pine stands may respond to commercial thinning with a net gain in cumulative volume at final harvest.
\end{abstract}

Keywords: lodgepole pine, commercial thinning, salvage thinning, mortality, stand volume

\section{RÉSUMÉ}

En Alberta (Canada), on s'attend à voir diminuer l'approvisionnement en pin lodgepole (Pinus contorta var. latifolia) à court ou moyen terme en raison des incendies forestiers passés et de l'épidémie du dendroctone du pin. L'éclaircie commerciale permettrait, à moyen terme, d'accroître l'approvisionnement en bois d'œuvre en diminuant le temps nécessaire pour que les tiges atteignent des dimensions commerciales tout en produisant de la fibre plus tôt en cours de rotation et en maintenant sur pied les peuplements matures sur une plus longue période de temps. Dans cette étude, nous avons évalué les effets de l'éclaircie commerciale dans des peuplements de divers âges. Dans les peuplements de 70 ans et moins, on a effectué éclaircie commerciale (CT) alors que dans les peuplements de plus de 70 ans il s'agissait d'une éclaircie de récupération (ST). On a mesuré la croissance et la survie des arbres à tous les cinq ans de 1996 à 2016 autant dans les peuplements éclaircis que dans les peuplements non éclaircis. Quinze ans après l'éclaircie, le volume des peuplements éclaircis était inférieur à celui des peuplements non éclaircis. Par contre, en tenant compte du volume prélevé lors de l'éclaircie, l'accroissement en volume dans les peuplements éclaircis était supérieur à celui des témoins pour les deux types d'éclaircies. Le DHP par arbre et le pourcentage de cime vivante étaient aussi plus élevés dans les peuplements éclaircis que dans les témoins. L'éclaircie aura favorisé la croissance en diamètre principalement chez les arbres de taille moyenne dans la $\mathrm{CT}$ et les arbres de taille moyenne à petite dans la ST. Globalement, les résultats indiquent que les peuplements naturels de pin lodgepole réagissent positivement à éclaircie commerciale et donnent un volume cumulatif plus élevé lors de la récolte finale.

Mots-clés : pin lodgepole, éclaircie commerciale, éclaircie de récupération, mortalité, volume du peuplement

\footnotetext{
${ }^{1}$ Department of Renewable Resources, University of Alberta, Edmonton, AB, Canada T6G 2H1; *Corresponding author: Sanatan@ualberta,ca

${ }^{2}$ Millar Western Forest Products Ltd., Whitecourt Wood Products Division, Whitecourt, AB, Canada T7S 1N2
} 


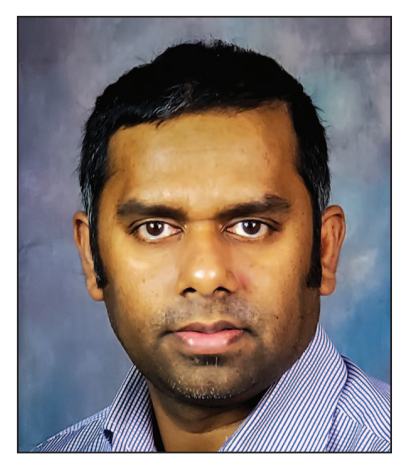

Sanatan Das Gupta

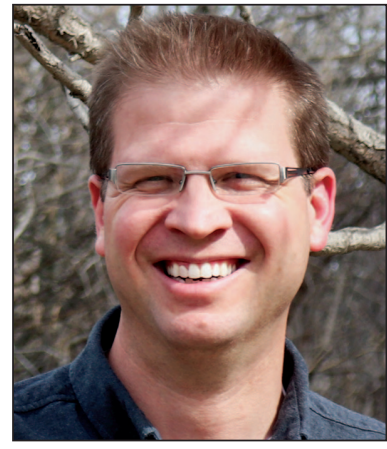

Bradley D. Pinno

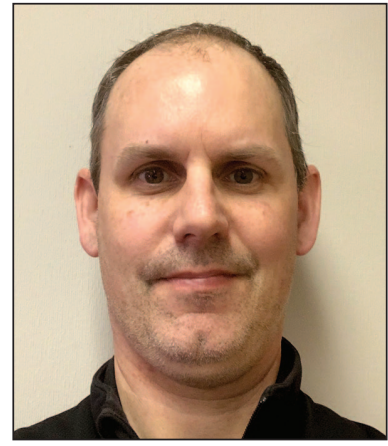

Tim McCready the effects of thinning on microclimatic variables (Whitehead et al. 2008), and to evaluate the responses of forest stands to silvicultural interventions (thinning and fertilization) (Stewart et al. 2006). However, most of the long-term studies reported in Stewart et al. (2006) are juvenile spacing and mechanical thinning treatments at a stand age of 25 years or less, and were not monitored for 20 years or

\section{Introduction}

Lodgepole pine regenerates vigorously after a wildfire with densities up to 10000 stems ha $^{-1}$ (Smithers 1961). High density in natural stands causes stagnation and self-thinning alone cannot maintain a normal stocking level for potential growth of the dominant trees (Cochran and Dahms 2000). Moreover, the natural mortality of smaller sized trees can increase fuel load and create a fire hazard (Oliver et al. 1996). Currently, there is an expected decrease in the short to midterm timber supply of lodgepole pine in Alberta due to the impacts of past fires and the mountain pine beetle outbreak (Schneider et al. 2010). Commercial thinning is a potential option for increasing mid-term sawlog timber supply in lodgepole pine stands.

The purpose of commercial thinning is to regularize the size and growth of a forest to maintain productivity throughout its life cycle (Petras 2002). Commercial thinning has the potential to allow access to saw timber earlier in the rotation, to reduce stand rotation length and mortality rates, and increase stand value and timber quality (Oliver et al. 1996; Miller 1997; Cameron 2002). There is also the potential to capture greater volume over the course of the rotation by harvesting future mortality (i.e., capturing natural drain). Information on thinning-induced changes in productivity at both stand and individual tree scale, and on mortality is required to properly manage lodgepole stands.

Commercial thinning in lodgepole pine has generally been found to be growth-promoting in terms of individual tree diameter and volume gain (Johnstone 1982a). However, periodic waves of density-dependent and density-independent mortality often reduce the benefit of thinning treatments (Navratil 1995; Axelson et al. 2010). Density-dependent mortality is commonly observed in young lodgepole pine stands, whereas age-dependent mortality may not be triggered until stands grow past 100 years (Smithers 1961; Johnstone 1982a; Tait et al. 1988).

The available literature on thinning studies in lodgepole pine in Alberta is mostly focused on pre-commercial thinning of highly dense fire-origin stands, and currently there are only five published reports of short-term re-measurements of commercial thinning trials that we are aware of (Smithers 1957; Walker and Johnson 1975; Johnstone 1982a; Navratil 2002; Stewart et al. 2006). Commercial thinning trials have been designed in British Columbia and Alberta to evaluate the susceptibility of thinned stands to mountain pine beetle, (Mitchell 1994; Whitehead et al. 2003), to determine more. Commercial thinning studies in lodgepole pine in other geographic regions are also scarce except for a few studies in Wyoming and Oregon which mostly focused on younger stands or rotational thinning (Dahms 1971; Cole 1995). Given the knowledge gap in the understandings of growth and yield responses to thinning in lodgepole pine stands, it is crucial to examine the effects of commercial thinning on mid to late-rotational stands (Navratil 2002). Moreover, there is also a need to understand the ecological processes driving the site-specific responses to thinning so that recommendations can be made for prioritizing sites for future commercial thinning. The main objectives of this study are to: (1) quantify the individual tree and stand-level growth and yield responses to commercial thinning in natural lodgepole pine stands; and, (2) to determine whether the thinning responses vary by stand age.

\section{Methods}

\section{Study area}

Lodgepole pine stands in the current study were located northwest of Whitecourt in the Lower and Upper Foothills natural subregions of Alberta. The sampling plots were selected based on their similarity in vegetation structure, ecosite class, dominant tree species, and site productivity. The main crop tree species was lodgepole pine with a lesser amount of white spruce and aspen. The sites generally fell under ecosite class 'd' (Beckingham and Archibald 1996). More information on the study plots can be found in Table 1 .

\section{Experimental design}

The study included thinning treatments applied on 11 installations ${ }^{3}$ with three within-site replications of the thinned plots. The thinned areas are multiple hectares in size with measurement plots of $400 \mathrm{~m}^{2}$ within each stand. Stands 40 70 years old at thinning were referred to as "Commercial Thinning" (CT) and stands greater than 70 years old at thinning were referred to as "Salvage Thinning" (ST) (Table 1). The CT treatment had five installations and the ST treatment had six in total. In addition to the three replicated thinned plots on each installation, each site also had an unthinned portion which was used as a control.

All plots were commercially thinned from below by removing the smaller diameter trees. Most of the installations

${ }^{3}$ Installations are the separate stands where silvicultural activities were carried out 
Table 1. Pre- and post-thinning stand and site characteristics of the commercial thinning (CT) and salvage thinning (ST) stands

\begin{tabular}{|c|c|c|c|c|c|c|c|c|c|c|c|c|}
\hline Treat. & $\begin{array}{l}\text { Install- } \\
\text { ation }\end{array}$ & $\begin{array}{l}\text { GPS } \\
\text { coordinates }\end{array}$ & $\begin{array}{l}\text { Elevation } \\
\quad(\mathrm{m})\end{array}$ & $\begin{array}{c}\text { Age at } \\
\text { thinning } \\
\text { (year) }\end{array}$ & $\begin{array}{l}\text { Density } \\
\text { (stems/ha) }\end{array}$ & $\begin{array}{l}\text { Mean } \\
\text { DBH } \\
(\mathrm{cm})\end{array}$ & $\begin{array}{c}\text { Basal } \\
\text { area } \\
\left(\mathrm{m}^{2} \mathrm{ha}^{-1}\right)\end{array}$ & $\begin{array}{c}\text { Top } \\
\text { height } \\
(\mathbf{m})\end{array}$ & $\begin{array}{l}\text { Mean } \\
\text { height } \\
\text { to live } \\
\text { crown } \\
\text { (m) }\end{array}$ & $\begin{array}{l}\text { Mean } \\
\text { live } \\
\text { crown } \\
\text { ratio }\end{array}$ & $\begin{array}{c}\text { Spacing } \\
\text { Factor } \\
(\%)\end{array}$ & $\begin{array}{c}\text { Mean } \\
\text { crown } \\
\text { width } \\
(\mathrm{m})\end{array}$ \\
\hline \multirow[t]{2}{*}{ vCT } & \multirow[t]{2}{*}{ AD703 } & $54.2217 \mathrm{~N}-$ & \multirow[t]{2}{*}{800} & \multirow[t]{2}{*}{43} & Pre 5575 & 8.99 & 37.9 & 15.8 & 7.87 & 0.35 & 7.75 & 1.46 \\
\hline & & $116.0608 \mathrm{~W}$ & & & Post 1675 & 11.2 & 15.6 & 16.3 & 9.09 & 0.33 & 14.9 & 1.82 \\
\hline \multirow[t]{2}{*}{ CT } & \multirow[t]{2}{*}{ TH109 } & $54.0333 \mathrm{~N}-$ & \multirow[t]{2}{*}{1150} & \multirow[t]{2}{*}{41} & Pre 3175 & 11.9 & 38.4 & 18.3 & 9.39 & 0.31 & 9.69 & 1.55 \\
\hline & & 116.2237 W & & & Post 1437 & 14.5 & 24.7 & 16.8 & 8.84 & 0.41 & 15.7 & 2.11 \\
\hline \multirow[t]{2}{*}{$\mathrm{CT}$} & \multirow[t]{2}{*}{ TH714 } & $54.0086 \mathrm{~N}-$ & \multirow[t]{2}{*}{1060} & \multirow[t]{2}{*}{43} & Pre 4300 & 11.0 & 44.4 & 20.1 & 10.1 & 0.32 & 7.58 & 1.55 \\
\hline & & $116.1971 \mathrm{~W}$ & & & Post 1566 & 13.2 & 22.5 & 18.9 & 11.3 & 0.30 & 13.4 & 1.66 \\
\hline \multirow[t]{2}{*}{ CT } & \multirow[t]{2}{*}{ WW603 } & $54.0657 \mathrm{~N}-$ & \multirow[t]{2}{*}{1130} & \multirow[t]{2}{*}{63} & Pre 2850 & 14.2 & 48.8 & 20.6 & 9.33 & 0.38 & 9.09 & 2.00 \\
\hline & & $116.5164 \mathrm{~W}$ & & & Post 1062 & 17.3 & 26.3 & 20.9 & 8.92 & 0.44 & 14.6 & 2.19 \\
\hline \multirow[t]{2}{*}{$\mathrm{CT}$} & \multirow[t]{2}{*}{601311} & 54.1778 N- & \multirow[t]{2}{*}{726} & \multirow[t]{2}{*}{57} & Pre 1950 & 14.9 & 43.7 & 25.4 & 10.2 & 0.39 & 8.91 & 2.99 \\
\hline & & $115.8415 \mathrm{~W}$ & & & Post 1325 & 17.1 & 38.1 & 25.7 & 11.2 & 0.43 & 10.7 & 3.01 \\
\hline \multirow[t]{2}{*}{ ST } & \multirow[t]{2}{*}{ WW606 } & $54.0775 \mathrm{~N}-$ & \multirow[t]{2}{*}{2000} & \multirow[t]{2}{*}{74} & Pre 3350 & 12.8 & 46.6 & 18.4 & 8.21 & 0.42 & 9.38 & 1.51 \\
\hline & & $116.4872 \mathrm{~W}$ & & & Post 1100 & 15.5 & 22.1 & 18.3 & 8.30 & 0.44 & 16.4 & 1.95 \\
\hline \multirow[t]{2}{*}{ ST } & \multirow[t]{2}{*}{ BM601 } & 54.1044 N- & \multirow[t]{2}{*}{980} & \multirow[t]{2}{*}{75} & Pre 3175 & 14.0 & 53.4 & 19.8 & 9.60 & 0.38 & 8.96 & 1.79 \\
\hline & & $116.0720 \mathrm{~W}$ & & & Post 1187 & 16.4 & 26.5 & 20.8 & 10.8 & 0.35 & 13.9 & 1.97 \\
\hline \multirow[t]{2}{*}{ ST } & \multirow[t]{2}{*}{670909} & $54.7852 \mathrm{~N}-$ & \multirow[t]{2}{*}{1082} & 112 & Pre 1025 & 24.8 & 54.1 & 29.1 & 12.9 & 0.37 & 10.7 & 3.24 \\
\hline & & $115.3115 \mathrm{~W}$ & & & Post 587 & 26.1 & 31.7 & 26.7 & 13.9 & 0.36 & 15.4 & 3.29 \\
\hline ST & 601321 & $54.1980 \mathrm{~N}-$ & 845 & 88 & Pre 1200 & 21.9 & 50.4 & 27.3 & 16.5 & 0.28 & 10.5 & 2.82 \\
\hline & & $115.8955 \mathrm{~W}$ & & & Post 650 & 20.4 & 22.9 & 23.9 & 14.9 & 0.35 & 16.4 & 2.56 \\
\hline ST & TH625 & $54.0585 \mathrm{~N}-$ & 1030 & 74 & Pre 3050 & 13.7 & 47.3 & 19.5 & 8.78 & 0.38 & 9.28 & 1.77 \\
\hline & & $116.2521 \mathrm{~W}$ & & & Post 1550 & 13.9 & 25.4 & 19.9 & 9.86 & 0.35 & 12.7 & 1.98 \\
\hline ST & TH608 & $54.0463 \mathrm{~N}-$ & 1053 & 75 & Pre 4975 & 11.8 & 63.1 & 20.7 & 9.26 & 0.35 & 6.84 & 1.89 \\
\hline & & $116.2547 \mathrm{~W}$ & & & Post 1850 & 14.7 & 34.5 & 21.8 & 10.2 & 0.37 & 10.6 & 2.21 \\
\hline
\end{tabular}

were thinned in 1999 and 2000 and growth measurements were conducted every five years until 2016. Two ST installations were thinned in 1996 and the measurement year 2013 was considered for comparing with other stands. Average pre-thinning density in CT was 4012 stems hectare ${ }^{-1}$ which was reduced to 1447 stems hectare ${ }^{-1}$ at thinning ( 64\% thinning). The average pre-thinning density in ST was 3120 stems hectare $^{-1}$ and was reduced to 1167 stems hectare $^{-1}$ at thinning ( $\sim 63 \%$ thinning). Pre-thinning spacing factors in these stands ranged from 8.7 to $9.4 \%$ before treatment; this increased up to $14.8 \%$ post-thinning (Table 1 ).

\section{Stand measurements}

All plots were measured pre-thinning and every five years post-thinning. Both individual tree-level and stand-level properties were measured and calculated in each plot. Individual tree-level properties included diameter at breast height (DBH), height and height to live crown, crown diameter, and volume. Stand-level properties included top height, quadratic mean diameter, basal area, merchantable volume, mortality, stand density index (SDI), and spacing factor (SF). DBH was measured at $1.3 \mathrm{~m}$, total height $(\mathrm{m})$ to the tallest live portion of the crown, and height to live crown from the ground level to the base of the live crown. The base of the live crown was set at the lowest reaching point of the lowest branch, not the point where this branch connects to the stem. To avoid triangulation errors during measurement, height to live crown was assessed by selecting a point on the bole that corresponded to the height of the lowest extent of the lowest branch, and measured to this point, instead of simply measuring to lowest extent of the branch. Most of the trees (99\%) in each plot were measured for height except for one CT plot where only $30 \%$ of the trees were measured. Missing tree heights were predicted using the provincial height-diameter equation (Huang 1994). Approximately, 80\% of the trees in each plot was measured for height to live crown and crown diameter. Tree health conditions, severity, and causes were also recorded. Top height was calculated from the 100 largest trees per hectare. The quadratic mean diameter is the tree diameter at average basal area and was calculated as follows: 
(1)

$$
\mathrm{QMD}=100 \sqrt{\frac{4 \text { BAsum }}{\pi \text { Ntrees }}}
$$

where, $\mathrm{QMD}=$ quadratic mean diameter; $\mathrm{BAsum}=$ sum of basal area of all trees in the plot; Ntrees = number of trees in the plot.

The two stand competition factors, stand density index (SDI) and spacing factor (SF), were calculated as follows:

(2) $\mathrm{SDI}=$ Density $\left(\frac{Q M D}{25}\right)^{1.6}$,

where, SDI = stand density index standardized to QMD of 25 cm (Reineke 1933).

(3) Spacing factor $=\frac{100}{\sqrt{\text { Density } * \text { Top Height }}}$ (Wilson 1946).

Merchantable volume was calculated using the provincial volume equation for softwood, hardwood, and lodgepole pine (Huang 1994). The $15 / 10$ merchantability criteria were used, where $15 \mathrm{~cm}$ is the minimum diameter outside bark at $30 \mathrm{~cm}$ stump height for a merchantable tree, and $10 \mathrm{~cm}$ is the top diameter inside bark for a merchantable tree (Stewart and Salvail 2017). Merchantable volume was calculated for each tree meeting the criteria and total merchantable volume per hectare was determined by summing the values for all trees in the plot and converting to per ha values.

\section{Statistical analysis}

Individual tree and stand-level growth responses to thinning were analyzed in relation to controls (unthinned plots). Increments in growth metrics (diameter, height, crown ratio, crown width, basal area, and merchantable volume) in CT and ST were calculated by taking the difference between the initial measurement and measurement at year 15 post-thinning and were compared between the thinned and unthinned stands.

Trees were grouped into different diameter classes to determine the thinning effects on size-dependent growth and to know if thinning favored trees of any specific size classes in $\mathrm{CT}$ and ST. Trees with a minimum 5-cm DBH were included in the analysis. A $2.5-\mathrm{cm}$ interval was used for trees in CT plots (class 1 to 11) and a 5-cm interval for trees in ST plots (class 1 to 8). Total merchantable volume 15 years post-thinning was also compared between treatments after accounting for the volume removed at thinning.

Periodic annual increment (PAI) in merchantable volume was calculated by taking the difference between the current and previous measurements and dividing by measurement interval. The mean annual increment (MAI) in merchantable volume was calculated by dividing the current volume by stand age. Relative tree mortality was calculated from the difference between the stand density immediately following thinning and the stand density measured at each 5-year interval. Mortality in different DBH size classes was calculated based on the density of each size class immediately after thinning compared with the density in year 15 post-thinning.

Individual and stand-level growth responses were compared between treatments using a mixed model analysis of variance (ANOVA). Thinning treatment was a fixed effect and plot was a random effect in the model. Since tree growth is related to initial tree size (Johnstone 1985), growth responses to thinning treatments were measured using analysis of covariance (ANCOVA) where initial tree size (height and $\mathrm{DBH}$ ) was used as a covariate. Normality and homogeneity of variance of model residuals were checked in all models. Between treatment effects were tested using a Tukey HSD and a two-sample $t$-test. Welch approximation to $d f$ is used in a $t$-test to account for unequal sample size and variances (Development Core Team 2016). Given the variability within plots, a significance level of 0.10 was used for all the comparisons. Statistical analyses were conducted using $\mathrm{R}$ program (R Development Core Team 2016).

\section{Results}

\section{Stand-level responses}

Total merchantable volume in year 15 post-thinning was greater in unthinned stands than in thinned stands in both CT and ST (Table 2; Fig. 1a). In CT, the mean merchantable volume increment in the thinned stands was $67 \mathrm{~m}^{3} \mathrm{ha}^{-1}$ by year 15 while the corresponding change in merchantable volume in the unthinned stands was $86 \mathrm{~m}^{3} \mathrm{ha}^{-1}$. However, when combined with the volume removed at thinning (average $=$ $46 \mathrm{~m}^{3} \mathrm{ha}^{-1}$ ), the gain in merchantable volume in the CT stands 15 years post-thinning was greater than in the controls

Table 2. Stand-level properties in CT and ST 15 years post-thinning; values are mean and standard error. Between group differences were determined based on t-test using a significance level of $\alpha=0.10$

\begin{tabular}{|c|c|c|c|c|c|c|c|}
\hline Treatment & $\begin{array}{l}\text { Top height } \\
\text { (m) }\end{array}$ & $\begin{array}{l}\text { Merchantable } \\
\text { vol. }\left(\mathrm{m}^{3} \mathrm{ha}^{-1}\right)\end{array}$ & $\begin{array}{l}\text { Basal area } \\
\left(\mathrm{m}^{2} \mathrm{ha}^{-1}\right)\end{array}$ & SDI & $\begin{array}{c}\text { 15-year } \\
\text { Mortality } \\
(\%)\end{array}$ & $\begin{array}{c}\text { 15- year } \\
\operatorname{PAI}\left(\mathrm{m}^{3} \mathrm{ha}^{-1}\right)\end{array}$ & $\operatorname{MAI}\left(\mathrm{m}^{3} \mathrm{ha}^{-1}\right)$ \\
\hline CT & $22.3(0.48)$ & $179.5(17.0)$ & $29.4(1.92)$ & $690.7(72.5)$ & $20.3(10.2)$ & $5.31(2.37)$ & $3.93(0.76)$ \\
\hline CT-control & $23.9(0.29)$ & $314.9(29.7)$ & $47.3(2.42)$ & $1126(83.9)$ & $42.8(5.84)$ & $4.22(1.89)$ & $4.20(0.45)$ \\
\hline P-value & 0.39 & 0.001 & $<0.001$ & 0.003 & 0.05 & 0.96 & 0.77 \\
\hline ST & $21.2(0.21)$ & $208.9(24.3)$ & $29(2.29)$ & $682(71.2)$ & $25.8(5.99)$ & $2.26(1.02)$ & $2.15(0.22)$ \\
\hline ST-control & $22.3(0.21)$ & $339.8(52.7)$ & $55.3(2.28)$ & $1324(62.3)$ & $28.5(10.4)$ & $3.32(0.84)$ & $3.51(0.59)$ \\
\hline P-value & 0.86 & 0.02 & $<0.001$ & $<0.001$ & 0.65 & 0.46 & 0.04 \\
\hline
\end{tabular}




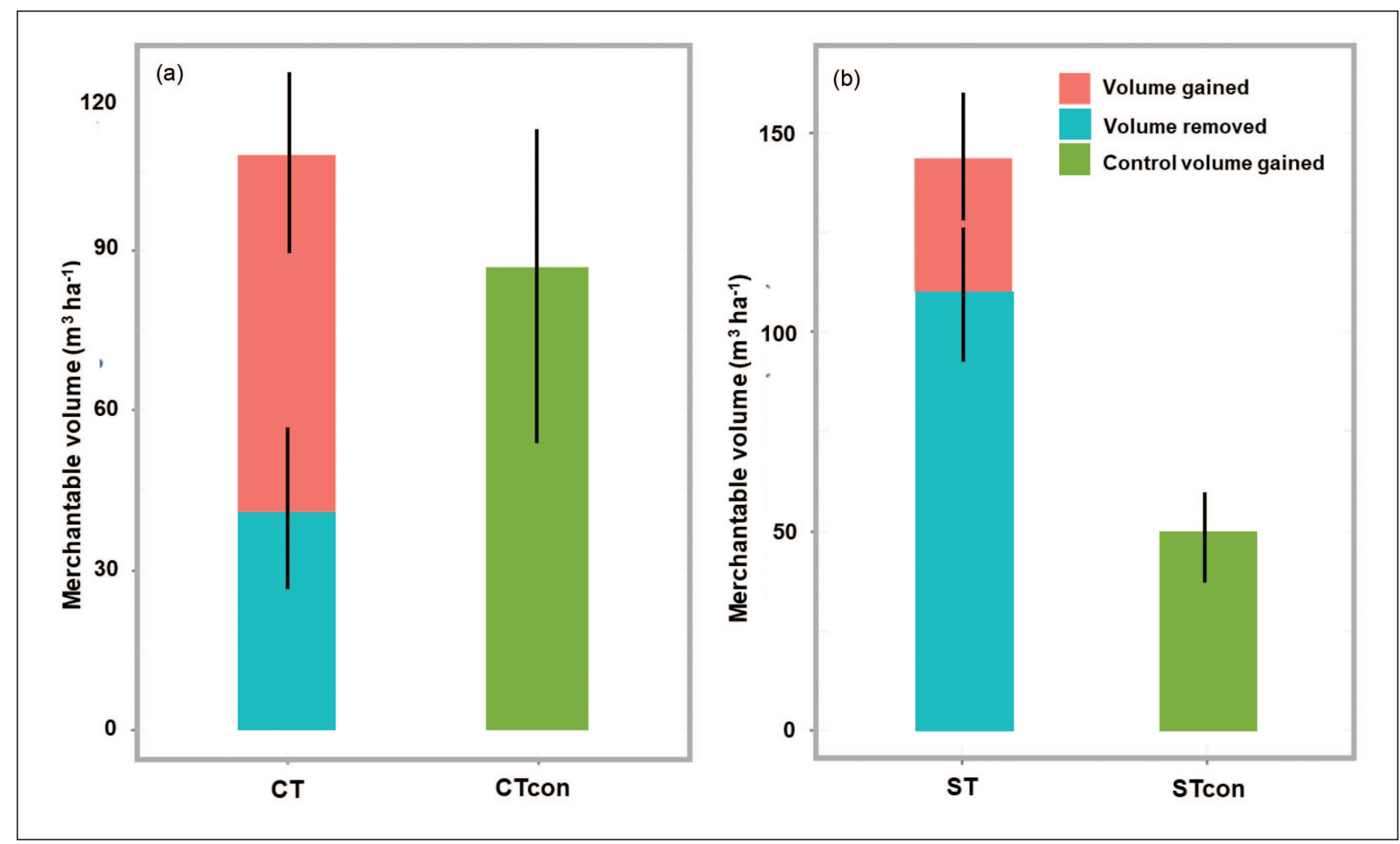

Fig. 1 Merchantable volume gain in year 15 post-thinning plus the volume removed at thinning in CT (a) and ST plots (b). Error bars indicate standard error. CTcon = CT control; STcon = ST control

(113 vs $86 \mathrm{~m}^{3} \mathrm{ha}^{-1}$ ) (Fig. 1b). In ST, merchantable volume increased in thinned stands by $40 \mathrm{~m}^{3} \mathrm{ha}^{-1}$ compared to $49 \mathrm{~m}^{3}$ $\mathrm{ha}^{-1}$ in the unthinned stands by year 15 . However, when combined with the volume removed at thinning (average $=$ $94 \mathrm{~m}^{3} \mathrm{ha}^{-1}$ ), thinned stands had a greater total merchantable volume gain (134 vs $49 \mathrm{~m}^{3} \mathrm{ha}^{-1}$ ) than the unthinned controls (Fig. 1c).

Periodic annual increment (PAI) from years 10-15 postthinning was greater in the thinned stands than in the controls (Tables 2 and 3). In CT, PAI was greater or equal in the thinned stands in four of the five installations. PAI was negative in installations WW603 and 601311 due to severe mortality (Table 3). In ST, PAI was greater or equal in the thinned stands compared to controls in three of the five installations (Table 4).

Mortality was lower in the thinned stands compared to controls. A 50\% decline was observed in the thinned stands compared to the controls in CT, whereas there was a $10 \%$ decrease with thinning in ST (Table 2). In CT installations, mortality 15 years post-thinning ranged from 125 to 775 stems ha ${ }^{-1}$ in the thinned stands and from 950 to 2350 stems $\mathrm{ha}^{-1}$ in the controls (Tables 1 and 3). In ST installations, mortality ranged from 25 to 625 stems ha $^{-1}$ in the thinned stand compared to 275 to 3650 stems ha $^{-1}$ in the controls (Tables 1 and 4).

Trees in smaller size classes had greater mortality than those in the medium to large size classes in both CT and ST. Most of the mortality occurred in trees $<15 \mathrm{~cm} \mathrm{DBH}$, which represented suppressed and intermediate trees (Fig. 2). Mor- tality gradually decreased with increasing size classes in both thinned and unthinned controls.

\section{Individual tree-level responses}

Average individual tree diameter growth 15 years post-thinning was greater in thinned stands than in unthinned controls in both CT (3.0 vs $1.8 \mathrm{~cm})$ and ST (1.5 vs $0.8 \mathrm{~cm})$ (Table 5). Diameter growth response to thinning also varied by size classes. In CT, gain in diameter increment with thinning occurred in trees with an initial diameter between 10.0 and $22.5 \mathrm{~cm}$, with the most relative gain in diameters $10.0-15.0 \mathrm{~cm}$, whereas trees larger than $22.5 \mathrm{~cm}$ and trees smaller than 10.0 $\mathrm{cm}$ were not affected by the thinning treatment (Fig. 3a). Likewise, gain in diameter increment in ST was observed in trees with an initial diameter between 10.0 and $30.0 \mathrm{~cm}$ with most relative gain in trees $10.0-20.0 \mathrm{~cm}$ in diameter (Fig. 3b). High density of small to medium-sized trees in both CT and ST stands further highlights the importance of the positive diameter increment in these size classes (Fig. $3 \mathrm{c}$ and Fig. 3d).

Crown diameter and live crown ratio also increased in thinned stands relative to unthinned controls, although the increment in crown width was only significant in ST (Table 5). On average, $59 \%$ of the stems had an increase in crown ratio compared to $43 \%$ in unthinned controls in ST (data not shown)

\section{Discussion and conclusions}

This study examined the effects of commercial thinning on growth and mortality in lodgepole pine stands in the Upper 
Table 3. Summary of stand-level properties of CT stands 15 years post-thinning; QMD = Quadratic mean diameter; PAI $\mathrm{MV}_{\mathrm{MV}}=\mathrm{Peri}_{-}$ odic annual increment in merchantable volume; $\mathrm{MAl}_{\mathrm{MV}}=$ Mean annual increment in merchantable volume

\begin{tabular}{|c|c|c|c|c|c|c|c|c|c|c|c|c|c|c|c|}
\hline \multirow[b]{2}{*}{ Plot } & \multirow{2}{*}{$\begin{array}{c}\text { Treat- } \\
\text { ment }\end{array}$} & \multicolumn{2}{|c|}{ QMD } & \multirow{2}{*}{$\begin{array}{c}\text { Merch. } \\
\text { vol. } \\
\text { removed } \\
\left(\mathrm{m}^{3} \mathbf{h a}^{-1}\right)\end{array}$} & \multicolumn{3}{|c|}{$\begin{array}{c}\text { Merchantable } \\
\text { volume }\left(\mathbf{m}^{3} \mathbf{h a}^{-1}\right)\end{array}$} & \multicolumn{2}{|c|}{$\begin{array}{l}\text { Total density } \\
(\text { St. ha } \\
\text { he })\end{array}$} & \multicolumn{2}{|c|}{$\begin{array}{l}\text { Merch. Density } \\
\quad\left(\text { St. } \mathbf{h a}^{-1}\right)\end{array}$} & \multicolumn{2}{|c|}{$\mathrm{PAI}_{\mathrm{MV}}\left(\mathrm{m}^{3}\right)$} & \multicolumn{2}{|c|}{$\mathrm{MAI}_{\mathrm{MV}}\left(\mathrm{m}^{3}\right)$} \\
\hline & & Con & Dec & & Total & Con & Dec & Con & Dec & Con & Dec & Con & Dec & Con & Dec \\
\hline \multirow[t]{2}{*}{ AD703 } & $\mathrm{CT}$ & 17.3 & 24.5 & 13 & 144 & 126 & 18 & 1566 & 50 & 900 & 50 & 6.40 & 0.60 & 2.17 & 0.31 \\
\hline & Control & 18.2 & 21.8 & - & 304 & 193 & 111 & 1775 & 525 & 925 & 350 & 6.20 & 2.00 & 3.33 & 1.91 \\
\hline \multirow[t]{2}{*}{ TH109 } & CT & 19.1 & - & 10 & 225 & 225 & - & 1533 & 25 & 1150 & - & 8.00 & - & 4.02 & - \\
\hline & Control & 17.9 & - & - & 274 & 274 & - & 2875 & 75 & 1475 & - & 7.60 & - & 4.89 & - \\
\hline \multirow[t]{2}{*}{ TH714 } & CT & 17.8 & - & 51 & 162 & 162 & - & 1458 & - & 975 & - & 5.40 & - & 2.89 & - \\
\hline & Control & 18.1 & 18.0 & - & 291 & 287 & 4 & 2825 & 425 & 1500 & 25 & 11.20 & 0.20 & 5.13 & 0.07 \\
\hline \multirow{2}{*}{ WW603 } & $\mathrm{CT}$ & 21.7 & - & 89 & 145 & 145 & - & 575 & - & 533 & - & -2.00 & - & 2.01 & - \\
\hline & Control & 21.0 & - & - & 272 & 272 & - & 1250 & - & 1050 & - & -2.20 & - & 3.40 & - \\
\hline \multirow[t]{2}{*}{601311} & CT & 25.1 & 27.1 & - & 334 & 294 & 40 & 825 & 75 & 650 & 75 & 4.60 & 2.00 & 4.08 & 0.56 \\
\hline & Control & 24.2 & 44.8 & - & 430 & 272 & 158 & 1025 & 175 & 650 & 100 & -0.40 & 2.20 & 3.78 & 2.19 \\
\hline
\end{tabular}

Table 4. Summary of stand-level properties of ST stands 15 years post-thinning. QMD = Quadratic mean diameter; PAI ${ }_{M V}=$ Periodic annual increment in merchantable volume; $\mathrm{MAI}_{\mathrm{MV}}=$ Mean annual increment in merchantable volume

\begin{tabular}{|c|c|c|c|c|c|c|c|c|c|c|c|c|c|c|c|}
\hline \multirow[b]{2}{*}{ Plot } & \multirow{2}{*}{$\begin{array}{l}\text { Treat- } \\
\text { ment }\end{array}$} & \multicolumn{2}{|c|}{ QMD } & \multirow{2}{*}{$\begin{array}{c}\text { Merch. } \\
\text { vol. } \\
\text { removed } \\
\left(\mathrm{m}^{3} \mathbf{h a}^{-1}\right)\end{array}$} & \multicolumn{3}{|c|}{$\begin{array}{c}\text { Merchantable } \\
\text { volume }\left(\mathbf{m}^{3} \mathbf{h a}^{-1}\right)\end{array}$} & \multicolumn{2}{|c|}{$\begin{array}{l}\text { Total density } \\
\left(\text { St. ha } \mathbf{h a}^{-1}\right)\end{array}$} & \multicolumn{2}{|c|}{$\begin{array}{l}\text { Merch. Density } \\
\quad\left(\mathrm{St} \mathrm{ha}^{-1}\right)\end{array}$} & \multicolumn{2}{|c|}{$\mathrm{PAI}_{\mathrm{MV}}\left(\mathbf{m}^{3}\right)$} & \multicolumn{2}{|c|}{$\operatorname{MAI}_{M V}\left(\mathrm{~m}^{3}\right)$} \\
\hline & & Con & Dec & & Total & Con & Dec & Con & Dec & Con & Dec & Con & Dec & Con & Dec \\
\hline \multirow{2}{*}{ WW606 } & ST & 19.1 & 26.3 & 62 & 134 & 115 & 19 & 762 & 50 & 600 & 50 & 2.00 & 0.40 & 1.29 & 0.21 \\
\hline & Control & 17.3 & - & - & 238 & 238 & - & 2725 & - & 1550 & - & 1.00 & - & 2.67 & - \\
\hline \multirow[t]{2}{*}{ BM601 } & ST & 18.4 & - & 148 & 142 & 142 & - & 966 & - & 833 & - & -2.00 & - & 1.57 & - \\
\hline & Control & 17.3 & - & - & 245 & 245 & - & 3100 & - & 1325 & - & 2.4 & - & 2.72 & - \\
\hline \multirow[t]{2}{*}{670909} & ST & 29.5 & 39.9 & 130 & 328 & 297 & 31 & 566 & 450 & 516 & 25 & 2.60 & 0.60 & 2.32 & 0.24 \\
\hline & Control & 19.2 & 33.0 & - & 360 & 342 & 18 & 2500 & 25 & 1725 & 25 & 2.40 & 0.40 & 2.67 & 0.14 \\
\hline \multirow[t]{2}{*}{601321} & ST & 23.8 & 28.2 & - & 242 & 230 & 12 & 575 & 125 & 575 & 25 & 1.80 & 0.20 & 2.23 & 0.12 \\
\hline & Control & 26.4 & 15.9 & - & 528 & 525 & 3 & 1050 & 175 & 950 & 50 & 5.20 & -0.60 & 5.77 & 0.03 \\
\hline \multirow[t]{2}{*}{ TH625 } & ST & 18.4 & - & 77 & 193 & 193 & - & 1425 & - & 1100 & - & 5.80 & 0.20 & 2.12 & - \\
\hline & Control & 17.3 & - & - & 325 & 325 & - & 3525 & - & 2000 & - & 5.80 & - & 3.57 & - \\
\hline $\mathrm{TH} 68^{\dagger}$ & & 20.4 & 15.6 & 96 & 260 & 258 & 2 & 1625 & 25 & 1075 & 25 & 2.40 & -0.2 & 2.80 & 0.02 \\
\hline
\end{tabular}

${ }^{\dagger}$ Installation TH608 did not have any control plot

and Lower Foothills region of west-central Alberta. Although similar commercial thinning studies in lodgepole pine are limited in the study area, our findings corroborate comparable studies in lodgepole pine stands in Alberta, British Columbia and elsewhere in North America (Johnstone and Cole 1988; Stewart et al. 2006; Lindgren and Sullivan 2013; Sullivan and Sullivan 2016).
Similar to other thinning studies (Cochran and Dahms 2000; Navratil 2002; Stewart et al. 2006; Stewart and Salvail 2017), the current study showed that thinning reduced merchantable volume and the overall stand volume in thinned stands was lower than in unthinned controls 15 years postthinning. However, the cumulative gain in volume, including the volumes removed at thinning and post-thinning vol- 

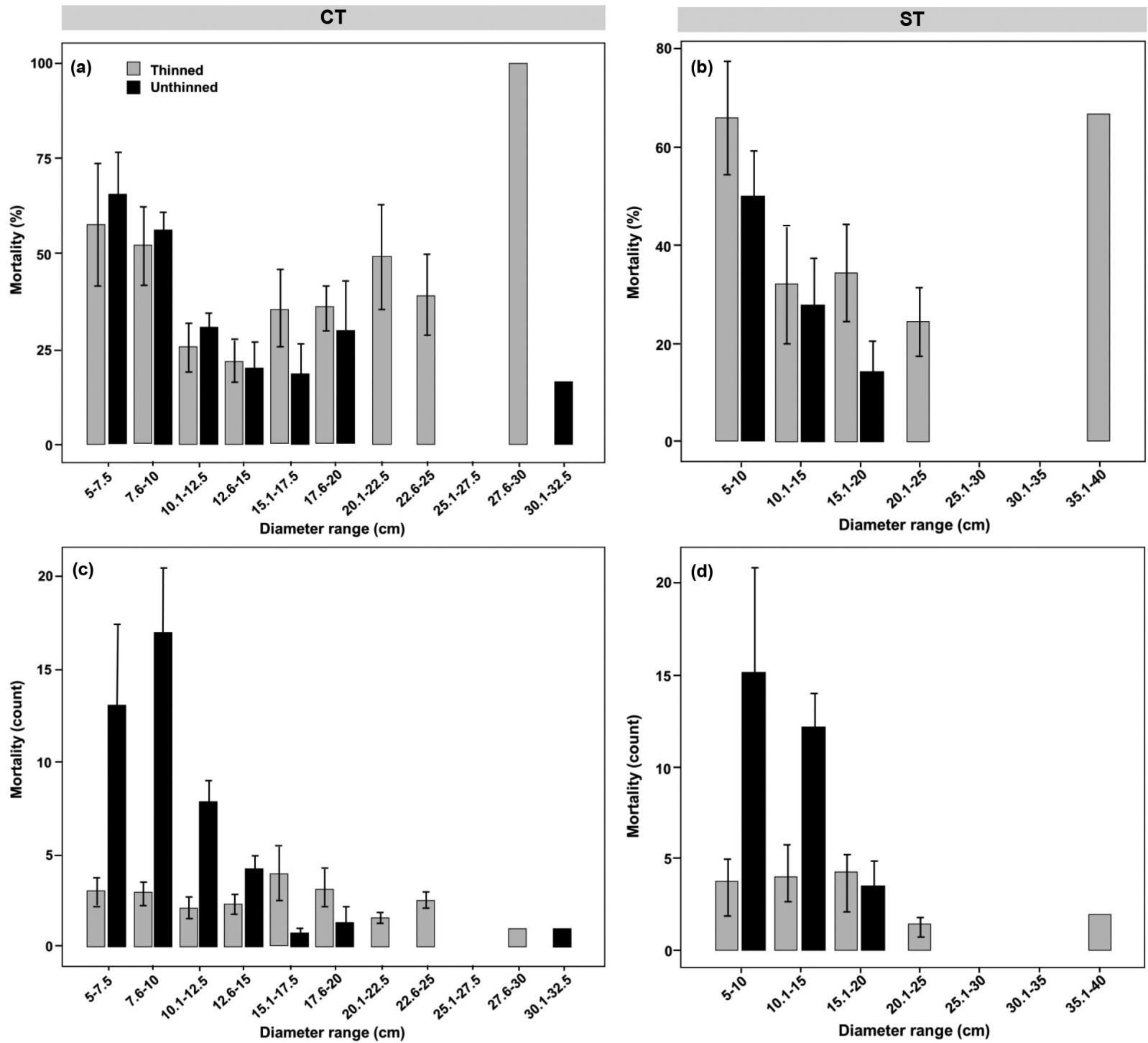

Fig. 2 Tree mortality (\% and count per $400 \mathrm{~m}^{2}$ ) in different DBH size classes in year 15 post-thinning in CT (a and $\mathbf{c )}$ and ST (b and $\mathbf{d}$ ) A $2.5 \mathrm{~cm}$ interval was used in CT and a $5 \mathrm{~cm}$ interval was used in ST. Error bars indicate standard error.

ume growth, indicates commercial thinning in natural lodgepole pine stands can be beneficial and has a yield advantage in both CT and ST age classes. The volume gain in thinned plots was due to relaxing growth suppression by creating more growing space around the remaining trees and capturing the merchantable volume that would otherwise be lost in mortality (Johnstone 1982b; Navratil 2002; Stewart et al. 2006). Thinning in older ST stands ( $>70$ years) can maximize this effect by increasing the merchantable volume removed during thinning. Although the volume gain in older stands was significantly lower (about 50\%) than the younger stands, the potential advantage of thinning mostly came from the volume removed at thinning.

Thinning also increased the growth of the remaining trees. In particular, increment in diameter and live crown ratio were significantly increased by thinning. In CT installations, major increment in diameter from thinning was seen in the mid-sized trees while in ST this effect was seen in both midand large-sized trees. The large-sized dominant trees did not respond to thinning, possibly because they were already the largest trees in the plots and had access to all available resources needed to maximize growth, while the mid-sized co-dominants would have experienced resource restrictions. At the other end of the tree size spectrum, the smallest trees also did not respond to thinning, possibly because they were in a suppressed social class with small live crowns which significantly reduced resource availability. Thinning may have increased the survival of these trees but it did not increase their growth.

The maximum advantage of thinning can be expected from trees having greater live crown ratios as they can immediately access resources (e.g., light, moisture, and space) com- 
Table 5. Increment in individual tree height, diameter, basal area, crown width and crown ratio in CT and ST stands over 15 years following thinning; significant differences were determined based on t-test using a significance level of $\alpha=0.10$

\begin{tabular}{lcccc}
\hline Treatment & $\begin{array}{c}\text { Height increment } \\
(\mathbf{m})\end{array}$ & $\begin{array}{c}\text { DBH increment } \\
(\mathbf{c m})\end{array}$ & $\begin{array}{c}\text { Crown width } \\
\text { increment }(\mathbf{m})\end{array}$ & $\begin{array}{c}\text { Live crown ratio } \\
\text { increment }\end{array}$ \\
\hline CT & $1.44(0.19)$ & $3.02(0.13)$ & $0.26(0.08)$ & $0.03(0.01)$ \\
CT-control & $1.84(0.36)$ & $1.81(0.19)$ & $0.19(0.18)$ & $-0.03(0.01)$ \\
\hline P-value & $<0.001$ & $<0.001$ & 0.24 & $<0.001$ \\
\hline ST & $0.62(0.20)$ & $1.48(0.20)$ & $0.12(0.13)$ & $0.01(0.01)$ \\
ST-control & $0.81(0.17)$ & $0.80(0.18)$ & $0.05(0.08)$ & $-0.02(0.01)$ \\
\hline P-value & 0.007 & $<0.001$ & 0.08 & $<0.001$ \\
\hline
\end{tabular}

CT
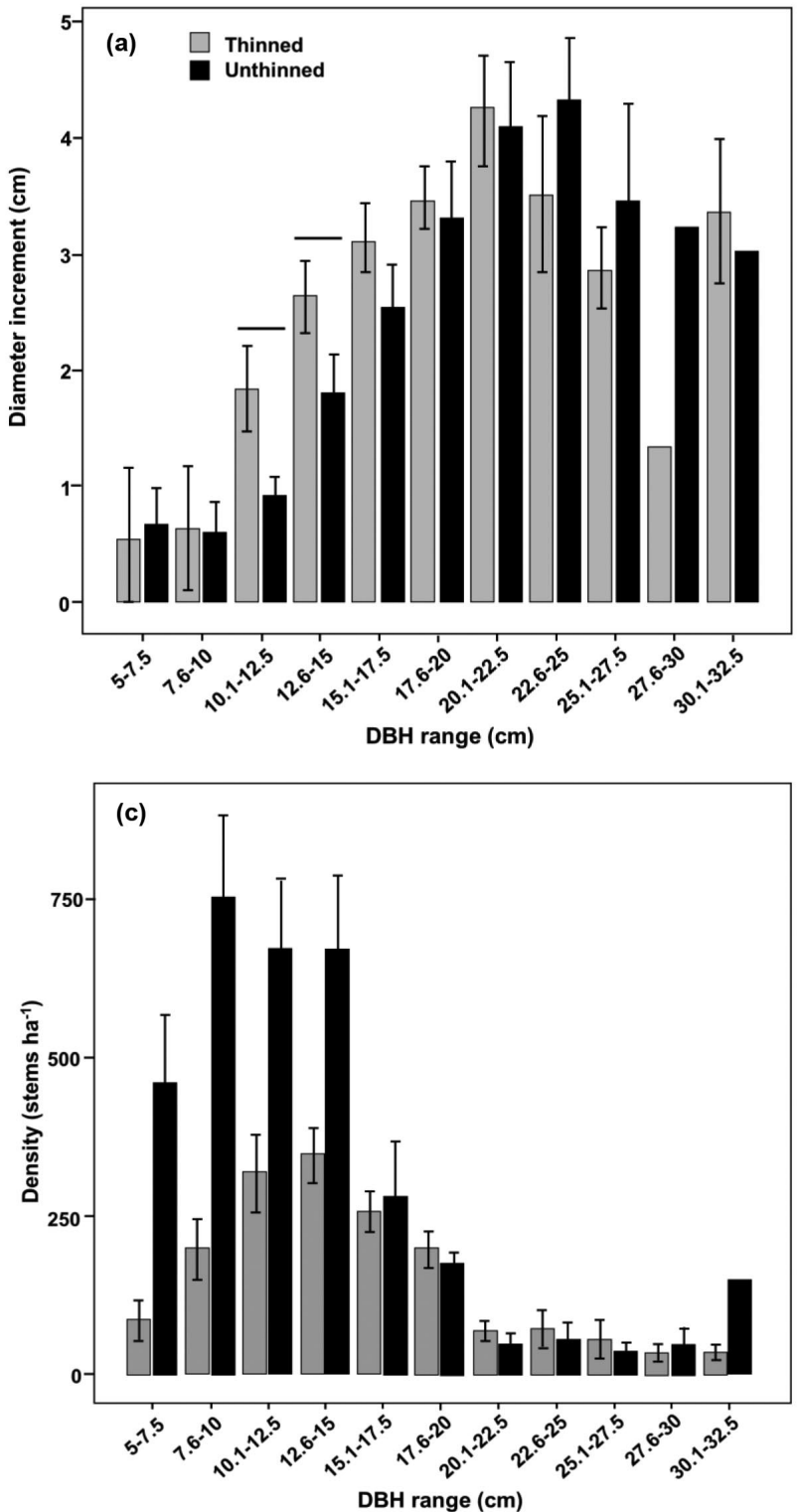

ST
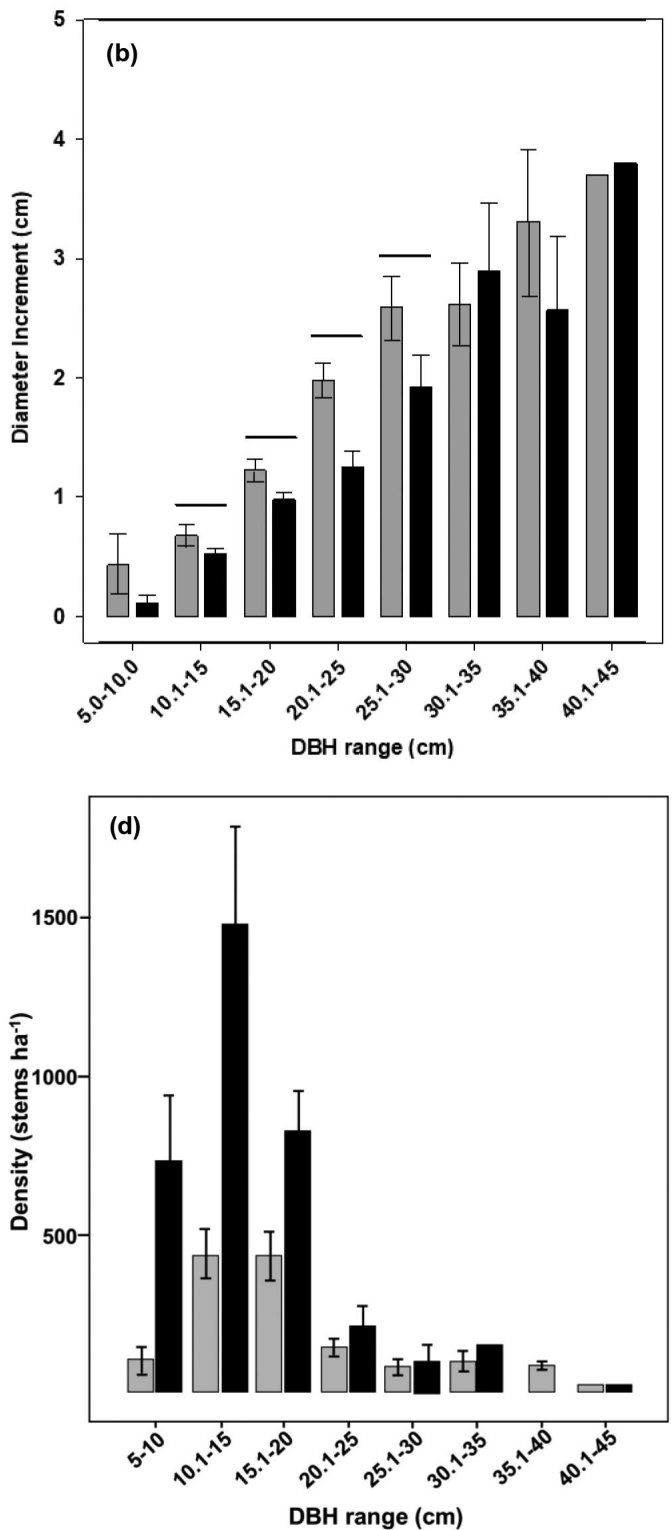

Fig. $3 \mathrm{DBH}$ increment in year 15 post-thinning (a and $\mathbf{b}$ ) and immediate post-thinning density of trees in different DBH size classes (c and $\mathbf{d}$ ) in CT and ST. Error bars indicate standard error. DBH class under same horizontal line indicates significantly different at 0.10 level based on ANCOVA analysis. A $2.5 \mathrm{~cm}$ interval was used in CT and a $5 \mathrm{~cm}$ interval was used in ST. 
pared to trees with low crown ratios. The similar diameter gain in ST for larger trees was possibly due to these trees having an already established crown volume. The findings confirm the general principles of thinning - that younger stands have a greater thinning response than older stands and the larger dominant and co-dominant trees have a greater response than smaller suppressed and intermediate trees (Johnstone and Cole 1988; Johnstone and van Thienen 2011). This suggests that commercial thinning can be practiced in natural lodgepole pine stands to achieve multiple goals ranging from decreasing rotation length to increasing lumber values. As demonstrated in several studies in lodgepole pine stands (Alexander 1960; Johnstone and Cole 1988; Johnstone and Pollack 1990; Johnstone and van Thienen 2011), thinning can increase individual tree growth and reduce rotation length by reducing the time to reach minimum merchantability criteria.

A maximum of $50 \%$ reduction in mortality was observed in the thinned stands of both CT and ST, although the effects in older stands were less evident due to age-related mortality factors. A significant reduction in mortality in thinned stands can be related to increased tree vigor and growth efficiency (Mitchell et al. 1983; Yao et al. 2001), greater competitive advantage (Cortini et al. 2017), and lower disease and insect infestation potential (Whitehead et al. 2001). Greater mortality in smaller trees in unthinned controls is expected due to self-thinning and suppression from larger trees (Barnes et al. 1997). The data from this current study does not allow for comment on the thinning effects on other non-yield characteristics such as tree health or susceptibility to beetle attack. Further studies should be designed to focus more on these aspects of thinning trials in lodgepole pine stands.

While commercial thinning has not been widely adopted in western Canada, the method has potential to overcome the impending timber supply shortage due to mountain pine beetle (MPB) infestation and catastrophic wildfire. Severe MPB outbreak has already induced a temporary uplift in annual allowable cut (AAC) in BC (Griess et al. 2019) and in some special cases in AB (Schneider et al. 2010) to allow licensees to salvage the standing dead volumes before their quality degrades. However, this increase in timber supply would last only for a short period ( 5 to 15 years) after which the regular supply of mature and harvestable timber would have to be restored back to the pre-disturbance level (Dhar et al. 2016; Griess et al. 2019). The gap in age structure created by these severe disturbances would not allow stands to support a sustainable timber supply and a mid-term timber shortage is unavoidable (Abbott et al. 2009). Commercial thinning, as demonstrated in this study, can be adopted as a tool to mitigate mid-term timber supply shortages in lodgepole pine stands. Thinning stands younger than 60 years old can have the greatest benefit, however, older stands can also be potential candidates for thinning if needed.

Although the findings from this study clearly indicate that commercial thinning in lodgepole pine stands can produce a significant gain in individual tree growth and cumulative stand volume, certain limitations in experimental design necessitated the exclusion of statistical comparisons in several instances. The sub-plots in some installations were not well replicated and the control plots in some installations were placed at a different location and had a different stand structure than the thinned plots. The within treatment variability in data reflects these discrepancies. Despite the few above mentioned operational limitations, a clear pattern of thinning effect has emerged in the tree and stand-level growth responses. The findings from this study will be useful in managing natural lodgepole pine stands for maximizing yield to mitigate wood supply shortfall in the near future, and possibly to avoid losses in crop trees due to insect attack (mountain pine beetle; Dendroctonus ponderosae Hopkins) and subsequent mortality.

\section{Acknowledgements}

We thank Millar Western Forest Products Ltd. for establishing the study, conducting all measurements, and providing access to the commercial thinning data. We also thank the members of the Silviculture Lab at the University of Alberta for their help during site visits. Funding for this current analysis was provided by the Natural Sciences and Engineering Research Council (NSERC).

\section{References}

Abbott, B., B. Stennes and G. Cornelis van Kooten. 2009. Mountain pine beetle, global markets, and the British Columbia forest economy. Can. J. For. Res. 39:1313-1321.

Alexander, R.R. 1960. Thinning lodgepole pine in the central Rocky Mountains. J. Forest. 58:99-104.

Axelson, J.N., R.I. Alfaro and B.C. Hawkes. 2010. Changes in stand structure in uneven-aged lodgepole pine stands impacted by mountain pine beetle epidemics and fires in central British Columbia. For. Chron. 86: 87-99.

Barnes, B.V., D.R. Zak, S.R. Denton and S.H. Spurr. 1997. Forest Ecology. $4^{\text {th }}$ edition. John Wiley and Sons. 792 pp.

Beckingham, J.D. and J.H. Archibald. 1996. Field guide to ecosites of west-central Alberta. Natural Resources Canada, Candian Forest Service, Northern Forestry Centre, Edmonton, Alberta, Special Report 9. 540 pp.

Cameron, A. D. 2002. Importance of early selective thinning in the development of long-term stand stability and improved log quality: A review. Forestry 75: 25-35.

Cochran, P. and W.G. Dahms. 2000. Growth of lodgepole pine thinned to various densities on two sites with differing productivities in central Oregon. USDA Forest Service. Pacific Northwest Res. Stat. Res. Pap. PNW-RP-520.

Cole, D.M. 1995. Managing lodgepole pine to yield merchantable thinning products and attain sawtimber rotations. USDA Forest Service, Intermountain Forest and Range, Res. Stat. Res. Pap. INTRP-482.

Cortini, F., P.G. Comeau, V.C. Strimbu, E.T. Hogg, M. Bokalo and S. Huang. 2017. Survival functions for boreal tree species in northwestern North America. Forest Ecol. Manag. 402:177-185.

Dahms, W.G. 1971. Fifty-five-year-old lodgepole pine responds to thinning. USDA Forest Service Research Note PNW-141. 13 pp.

R Development Core Team. 2016. R: A Language and Environment for Statistical Computing. The R Foundation for Statistical Computing, Vienna, Austria.

Dhar, A., L. Parrott and C. D. Hawkins. 2016. Aftermath of mountain pine beetle outbreak in British Columbia: Stand dynamics, management response and ecosystem resilience. Forests 7:171.

Griess, V. C., C. D. Man, A. D. Polinko and J. Spies. 2019. Mitigating midterm timber supply shortage using commercial thinning operations. A case study from British Columbia, Canada. Forest Ecol. Manag. 443:1-18.

Huang, S. 1994. Ecologically based individual tree volume estimation for major Alberta tree species. Report No.1. Individual tree volume estimation procedures for Alberta: Methods of formulation 
and statistical foundations. Alberta Land and Forest Service, Edmonton, AB. 120 pp.

Johnstone, W.D. 1982a. Heavy thinning accelerates growth of 77year-old lodgepole pine. Forest Management Note, Northern Forest Research Centre, Canada [No. 16].

Johnstone, W.D. 1982b. Juvenile spacing of 25-year-old lodgepole pine in western Alberta. Canadian Forest Service, Edmonton, AB, Information Report NOR-X-244.

Johnstone, W.D. 1985. Thinning lodgepole pine. In: Baumgartner, D.M., Krebill, R.G., Arnott, J.T., Weetman, G.F. (Eds.), Lodgepole Pine: The Species and Its Management. Washington State University Cooperative Extension, Spokane, Washington, USA, and Vancouver, BC, pp. 253-262.

Johnstone, W.D. and D. M. Cole. 1988. Thinning lodgepole pine: A research review. In: Proceedings - Future forests of the mountain west: A stand culture symposium. USDA Forest Service, Intermountain Research Station (Ogden, Utah) General Technical Report INT-243. pp. 160-164.

Johnstone, W. and J. Pollack. 1990. The influence of espacement on the growth and development of a lodgepole pine plantation. Can. J. For. Res. 20:1631-1639.

Johnstone, W.D. and F. van Thienen. 2011. The effects of plantation density on the growth and yield of lodgepole pine: 20-year results. Extension Note-British Columbia Ministry of Forests and Range Program, Victoria, B.C. Exten. Note 102. http://www.for.gov. bc.ca/hfd/pubs/Docs/En/En102.htm

Lindgren, P. M. and T. P. Sullivan. 2013. Long-term responses of tree and stand growth of young lodgepole pine to pre-commercial thinning and repeated fertilization. Forest Ecol. Manag. 307:155-164

Miller, G. W. 1997. Stand dynamics in 60-year-old Allegheny hardwoods after thinning. Can. J. For. Res. 27:1645-1657.

Mitchell, J.L. 1994. Commercial thinning of mature lodgepole pine to reduce susceptibility to mountain pine beetle. FRDA Report 224, Forest Engineering Research Institute of Canada, Vancouver, B.C.

Mitchell, R., R.H. Waring and G. Pitman. 1983. Thinning lodgepole pine increases tree vigor and resistance to mountain pine beetle. Forest Science 29: 204-211.

Navratil, S. 1995. Minimizing wind damage in alternative silviculture systems in boreal mixedwoods. Natural Resources Canada, Canadian Forest Service, Northern Forestry Centre, Edmonton, AB. Canada-Alberta Partnership in Forestry Report 124.

Navratil, S. 2002. A lodgepole pine commercial thinning trial in Kananaskis, Alberta: 58-year results. Natural Resources Canada, Candian Forest Service, Northern Forestry Centre, Edmonton, AB and Weldwood Canada Ltd., Hinton, AB.

Oliver, C.D., B.C. Larson and C. Oliver. 1996. Forest Stand Dynamics. Wiley New York.

Petras, R. 2002. Age and diameter classes or growth stages as criteria for the implementation of thinning. J. For. Sci. 48: 8-15.
Reineke, L.H. 1933. Perfecting a stand-density index for even-aged forests. J. Agric. Res. 46 (7): 627-638

Schneider, R.R., M.C. Latham, B. Stelfox, D. Farr and S. Boutin. 2010. Effects of a severe mountain pine beetle epidemic in western Alberta, Canada under two forest management scenarios. Int. J. For. Res. doi:10.1155/2010/417595

Smithers, L. 1957. Thinning in lodgepole pine stands in Alberta. Department of Northern Affairs and Natural Resources, Forest Res. Div. Tech. Note 52, 26 pp.

Smithers, L. 1961. Lodgepole pine in Alberta. Department of Forestry, Government of Canada Bulletin 127. Government of Canada, Ottawa; 153 pp.

Stewart, J.D. and J. Salvail. 2017. Evaluation of Precommercial Thinning of Lodgepole Pine from Long-term Research Installations in Alberta. Natural Resources Canada, Can. For. Serv., Can. Wood Fibre Cent., Edmonton, AB. Inf. Rep. FI-X-16.

Stewart, J. D., T. N. Jones and R. C. Noble. 2006. Long-term lodgepole pine silviculture trials in Alberta: History and current results. Can. For. Serv., Northern Forestry Centre, Edmonton, AB.

Sullivan, T. P. and D. S. Sullivan. 2016. Acceleration of old-growth structural attributes in lodgepole pine forest: Tree growth and stand structure 25 years after thinning. Forest Ecol. Manag. 365: 96-106.

Tait, D. E., C. J. Cieszewski, and I. E. Bella. 1988. The stand dynamics of lodgepole pine. Can. J. For. Res. 18: 1255-1260.

Walker, N. and H. Johnson. 1975. Growth and regeneration response to various stand treatments in a mature lodgepole pine stand. Environ. Can., For. Serv., North. For. Res. Cent. Edmonton, Alberta. NOR-X-137, 1-16.

Whitehead, R.J., P. Martin and A. Powelson. 2001. Reducing stand and landscape susceptibility to mountain pine beetle. British Columbia Ministry of Forests, Victoria, BC, Canada. 12 pp.

Whitehead, R.J., L. Safranyik, G. Russo, T.L. Shore and A.L. Carroll. 2003. Silviculture to reduce landscape and stand susceptibility to the mountain pine beetle. In: Shore, T.L., Brooks, J.E., Stone, J.E. (Eds.), Mountain Pine Beetle Symposium: Challenges and Solutions, October 30-31, 2003, Kelowna, British Columbia, Canada, Report BC-X-399, Natural Resources Canada, Canadian Forest Service, Pacific Forestry Centre, Victoria, BC, pp. 233-244.

Whitehead, R. J., G. Russo, B. Hawkes, S. Taylor, B. Brown, O. Armitage, H. Barclay and R. Benton. 2008. Effect of commercial thinning on within-stand microclimate and fine fuel moisture conditions in a mature lodgepole pine stand in southeastern British Columbia. Canadian Forest Service, Canadian Wood Fibre Centre. British Columbia, Information Report, FI-X-004.

Wilson, F. 1946. Numerical expression of stocking in terms of height. J. Forestry 44: 758-761.

Yao, X., S.J. Titus and S.E. MacDonald. 2001. A generalized logistic model of individual tree mortality for aspen, white spruce, and lodgepole pine in Alberta mixedwood forests. Can. J. For. Res. 31: 283-291. 